Originalveröffentlichung in: Baumgarten, A., Assmann, J., Stroumsa, G. G. (Hg.), Self,

Soul and Body (Studies in the history of religions 78), Leiden 1998, S. 384-403

\title{
A DIALOGUE BETWEEN SELF AND SOUL: PAPYRUS BERLIN 3024
}

\author{
Jan Assmann
}

The ancient Egyptian speaks of "his djet-body," "his ha'u-body," "his belly," "his heart," "his Ba-soul," "his Ka-soul," "his shadow," "his name" as a multiplicity of constituents or aspects of his person. The possessive "his" refers to the "self" that owns, governs, and controls this multiplicity. In normal life, the unity or unanimous cooperation of these different components is no problem. Death, however, dissolves this interior community. Yet there are ritual means to overcome this critical situation and to achieve a new and even more powerful state of personality where the different constituents or aspects of the person are brought into new forms of interaction and cooperation. The Egyptian concepts of death and immortality are based on this idea of the person as a community that is threatened with dissolution but is capable of reintegration. This explains why the Egyptians were as concerned with preserving the body by mummification as with equipping the soul with knowledge about the hereafter and building a tomb in order to keep the name remembered in the world of the living. Also life after death was believed to succeed only in a "constellative" way (see below).

\section{Integration and Dissociation of Self}

There are, however, extreme situations during an individual's lifetime where the unifying and centralizing control which the "self" exerts over its multiple constituents is severely threatened. Such a situation is characteristic of the malady of love or other strong desires, of extreme terror, and of old age.

The malady of love is described in terms of dissociation of heart and self and the ensuing disintegration of personal identity:

My heart quickly scurries away

when I think of your love (=my love of you).

It lets me not act sensibly,

it leaps from its place. 
It lets me not put on a dress, nor wrap my scarf around me;

I put no paint upon my eyes, I'm even not anointed. ${ }^{1}$

The same motif of a dissociation of heart and self occurs in a text where it describes the longing of a man for his home-town, Memphis:

I am awake but my heart sleeps.

My heart is not in my body.

Evil has caught all my limbs:

my eyes are weary of seeing,

my ear does not hear,

my voice is hoarse,

all my words are perverted. ${ }^{2}$

Incidentally, "I am awake but my heart is sleeping" (wrš.j jw jb.j $n m^{\text {' } w) ~ i s ~}$ the exact inversion of a famous verse in the Song of Songs: "I slept but my heart was awake" (3nj jsnh w-lbb.j' $d$ 5.2). Common to both texts is the idea of a dissociation of heart and self, the speaking "I." In the Egyptian text, this is expressed by the motifs of sleeping or weariness, and of spatial removal: "My heart is not in my body." The same expression occurs in the story of Sinuhe. There it refers to a fit of extreme fear, when Sinuhe finds himself in the presence of Pharaoh:

Stretched out on my belly I did not know myself before him, while this god greeted me pleasantly.

I was like a man seized by darkness.

My Ba was gone, my limbs trembled, my heart was not in my body,

I did not know life from death. ${ }^{3}$

Thus the coherence of the person during life-time is problematic because of the heart's unsteadiness, its susceptibility to leap from its place, to flutter, to scurry away under the influence of strong emotions and passions like fear, terror, erotic desire, and yearning. In cases of extreme terror, even the $\mathrm{Ba}$ abandons the self.

${ }^{1}$ Chester Beatty C 2,9 C 3,1; See M.V. Fox, The Song of Songs and the Ancient Egyptian Love Songs (Madison, 1985) pp. 20f., 53 Nr. 34.

2 Anastasi IV, 4.11-5.5; H.A. Gardiner, Late Egyptian Miscellanies, Bibl. Aeg. VII (Brussels, 1937) p. 39; R.A. Caminos, Late Egyptian Miscellanies (Oxford, 1952) pp. 150-152; S. Schott, Altägyptische Liebeslieder (Zürich, 1950) 116 Nr. 57; J. Assmann, Ägyptische Hymnen und Gebete (Zürich, 1975) Nr. 184.

${ }_{3}$ Sinuhe B 252-56. ed. A.M. Blackman, Middle Egyptian Stories, Bibl. Aeg. II (Brussels, 1932) p. 37; R. Koch, Die Erzählung des Sinuhe, Bibl. Aeg. XVII (Brussels, 1990) p. 74; transl. M. Lichtheim, loc. cit., 231. 
Social isolation is also included among the extreme situations where a person is threatened with disintegration. The Egyptian person is not only conceived of as an "interior community or constellation" composed of members that are equally referred to as "his": his dresses, ornaments, insignia, staff, scepter, weapons, house, tomb and, above all, social relations - husband or wife, father and mother, children and children's children, servants, clients, admirers, enemies, etc.

A person comes into being, lives, grows, and exists by building up such a sphere of social and bodily "constellations," and is annihilated if this sphere is destroyed. Therefore, I propose to call this concept of person "constellative." A constellative anthropology stresses the ties, roles, and functions that bind the constituent parts together. It abhors the ideas of isolation, solitude, self-sufficiency, and independence, and considers them symptoms of death, dissolution, and destruction. Life is interdependence, interconnection, and communication within those webs of interaction and interlocution that constitute reality. One lives only with and by others or, as the Egyptian proverb puts it: "One lives if one is led by another" ("nh w'ssm sw kjj). ${ }^{4}$

In cases of solitude and isolation when the exterior constellations of the person have vanished, a self is threatened by death if it cannot find a partner within its interior community. Thus, in a tale about a sailor who is the sole survivor of a shipwreck and finds himself stranded on a desolate island, we read: "I was cast on an island by a wave of the sea. I spent three days alone, with my heart as companion." This is the type of a literary form that we may term "interior dialogue." It is characteristic of situations of distress and solitude. Only in situations of extreme despair and isolation, does a "self" turn to speaking to his "heart" or his "Ba."

A well known example of such an interior dialogue is Complaints of Khakheperre-sonb. ${ }^{6}$ The speaking self is bewailing the desperate state of

${ }^{4}$ Metternichstele M 50, C.E. Sander-Hansen, Die Texte der Metternichstele, Analecta Aegyptiaca VII (Kopenhagen, 1956) pp. 35f., 41; A. Klasens, A Magical Statue Base (Socle Behague) in the Museum of Antiquities at Leiden, Oudheidkundige Mededelingen uit het Rijksmuseum van Oudheden te Leiden N.R. XXXIII (Leiden, 1952) pp. 10, 52; H. Sternberg, "Die Metternichstele," in O. Kaiser (Hrsg.), Texte aus der Umwelt des Alten Testaments (TUAT) Bd.II.3, Rituale und Beschwörungen II (Gütersloh, 1988) p. 376.

${ }^{5}$ Pap. St. Petersburg 1115, 39-44; trans. M. Lichtheim, Ancient Egyptian Literature I (Berkeley, 1973) p. 212.

${ }^{6}$ Writing Board British Museum No. 5645, ed. A.H. Gardiner, The Admonitions of an Egyptian Sage (Leipzig, 1909) pp. 95-110; trans. M. Lichtheim, op. cit., pp. 145149 . 
the world. "The land," it says, "breaks up, is destroyed, becomes a wasteland. Order is cast out, chaos is in the council hall. The ways of the gods are violated, their offerings neglected. The land is in turmoil, there is grieving everywhere." Another heart would bend," the self continues, "but a heart strong in distress: it is a comrade to its lord." Thus, the self addresses his heart and breaks into an interior dialogue:

Come my heart, I speak to you, answer me my sayings!

Unravel for me what goes on in the land,

Why those who shone are overthrown.

\section{The Conflict of Self and Soul}

The most important example of such an interior dialogue is the text on Berlin Papyrus 3024, known as the "Tired of Life" ("Der Lebensmüde") or the Dialogue of a Man and his Ba. In this text, the "self" is not only addressing its $\mathrm{Ba}$, but is answered by it in a true rhetorical combat. This rather unique setting differs widely from those cases where a lonely person addresses his "heart"; still, we would miss an important point if we did not consider this text as an extreme case of interior dialogue. In normal life, a dialogue between the "I" and his "Ba" does not occur; the setting as such refers to an exceptional situation.

The Dialogue of a Man and his $B a$ is certainly the most frequently cited Egyptian text outside the field of Egyptology. Alfred Weber and Karl Jaspers mention it as the one great exception in an otherwise dull or unapproachable literature. Erik Voegelin devoted an article to this text. ${ }^{7}$ The favor this text enjoys outside the narrow circle of Egyptologists is the more striking, as among that group it is held to be extremely difficult and problematic, and many questions remain open. ${ }^{8}$ Some of the difficulties are created by the loss of the begin-

7 "Immortality: Experience and Symbol" (The Ingersoll Lecture 1965. Harvard University), in The Harvard Theological Review 60 (1967): 235-279.

${ }^{8}$ The "Lebensmüde" has been the subject of innumerable studies. The editio princeps is that of Adolph Erman, Das Gespräch eines Lebensmüden mit seiner Seele (Berlin, 1896). A major breakthrough in understanding the text was achieved by R.O. Faulkner, "The Man who was Tired of Life," JEA 42 (1956): 21-40; Winfried Barta, Das Gespräch eines Manne mit Seinem Ba (MÄS 18, 1969) and Hans Goedicke, The Report about the Dispute of a Man with his Ba (Baltimore, 1970) devoted entire monographs to the text without improving either its reading or its interpretation in any decisive way. 
ning. We do not know whom the two partners of the dialogue are addressing, apart from each other; there seem to be others present to whom they are appealing.

The two partners consist of an "I" who appears as the speaker reporting the dispute, and his "Ba"; I will be referring to them in the course of this paper as "Self" and "Soul." In the first part of the dialogue, the "Self" and its "Soul" dispute the question of the right way of death and burial. The fragment starts somewhere in a speech of the Soul, which is mostly lost. The only intelligible words are "their tongue is not partial." It is just a tiny trace of the soul's speech, but it provides a precious hint as to the general setting of the dialogue, because these words can only refer to the judges passing a verdict on the dead. ${ }^{9}$ The text reverts to them later on. We are to understand that the Soul tells the Self that it is going to bring their case before the judges of the dead because they will pass an impartial sentence.

There are texts where a similar motif occurs. In a text known as the "Eloquent Peasant," a plaintiff has long been trying to receive justice, but in vain. Eventually he threatens the magistrate to bring the case before Anubis:

I have been pleading to you, and you have not listened to it.

I shall go and plead about you to Anubis! $!^{10}$

The speaker does not threaten to visit a temple of Anubis and supplicate the god by way of prayer and sacrifice. This is not a possible form of communicating with a god in the Middle Kingdom Egypt. ${ }^{11}$ The gods are to be confronted only by priests, indirectly in a statue ritual or directly after death. Anubis belongs to the realm of the dead:

Barta's book, however, has the merit of containing an important collection of passages concerning the $\mathrm{Ba}$, and a comprehensive bibliography up to 1969. An interesting and brilliantly written booklet by Odette Renaud, Le Dialogue du Désepéré avec son âme. Une Interprétation littéraire (Genève, 1991) focuses on the literary qualities of the text and discovers a convincing structure. See also V.A. Tobin, "A Re-assessment of the Lebensmüde," BiOr (1991): 341-363.

${ }^{9}$ For the Egyptian idea of judgment after death, see John Gwyn Griffiths, The Divine Verdict. A Study of Divine Judgement in the Ancient Religions. Studies in the History of Religions (Supplements to NUMEN LII [Leiden, 1991]).

10 Eloquent Peasant B2 113-115, ed. R. B. Parkinson, The Tale of the Eloquent Peasant (Oxford, 1991) p. 47.

${ }^{11}$ Cf. the different conceptions of appealing to divine justice in Psalm 7, and in Egyptian texts of the later New Kingdom, such as "the prayers of a defendant" (AHG) or Bata's plea to the sun god in the Tale of the Two Brothers. 
He leads the deceased across the threshold between this world and the other world, the kingdom of Osiris; he assists the dead in the post mortem judgment. The plaintiff is threatening to commit suicide and to present himself before the last judgment, where his plea will be listened to and decided according to justice. From the course of the plot, it becomes clear that something like this is meant. These words are sufficient to immediately stir up the lethargy of the magistrate. An Egyptian judge must always take into account the possibility that the defendant has a $\mathrm{Ba}$ and might - in the form of his $\mathrm{Ba}$ - appeal to the court of Osiris for justice. Thus, in the instruction for king Merikare, the king is severely advised not to use the death penalty except in the case of rebellion:

Do not kill, it does not serve you, punish with beatings, with detention, thus will the land be well ordered.

Except for the rebel whose plans are found out, for God knows the treason plotters, God smites the rebels in blood.

(...)

Do not kill a man whose virtues you know, with whom you once chanted the writings, who was brought up ... before god, who strode freely in the secret place. The Ba comes to the place it knows, it does not miss its former path.

No kind of magic holds it back, it comes to those who give it water. ${ }^{12}$

The $\mathrm{Ba}$ is the freely moving part of the person; it is able to commute between different worlds such as heaven, earth, and netherworld. It is not the person himself, but his representative. Thus, when one says, "I will go and plead to Anubis," he means that his Ba will go. In our case, the $\mathrm{Ba}$ is making a similar threat when alluding to the impartiality of the judges in the last tribunal. But it does not intend to represent the person; instead, it is willing to go on his own behalf and to leave the person behind.

The dialogue thus takes place in this world, and the $\mathrm{Ba}$ is threatening to cross the threshold of death and to bring the case before the court of Osiris. The Self confirms this interpretation in its answer: "My Ba will not converse with me." Obviously the Soul has warned the Self that it will break off the conversation with the partial Self and

${ }^{12}$ Merikare, after Lichtheim, pp. $100 \mathrm{f}$. 
address the impartial judges in the netherworld who are only to be reached by dying or "parting" ( away," often has the meaning "to die"). The Self is using precisely this key-word: "My Soul shall not go! It shall attend to me in this!" and "It shall not happen to him that he flees on the day of affliction!"13 "Look," the Self continues, and now seems to address the judges:

My Soul resists me but I do not listen to it.

It drags me toward death before I come to it,

Casts me on fire as to burn me!

The Self wants that the soul

should be near me on the day of affliction,

It shall stand on yonder side as does the "Nehepu"

Because such is one who goes out, that he will bring himself back.

We do not know what "Nehepu" means and, therefore, cannot fully grasp the meaning of these sentences. But I think it is clear that the intention of the Ba to "go away" is rejected. The issue seems to be the separation of Self and Soul in death, which is the aim of the Soul and which the Self is trying to prevent. One should keep in mind that the Egyptian problem is not the immortality of the soul, but the establishment of a connection and cooperation between the surviving components of the person, such as body, heart, and soul. The Self continues:

$\mathrm{My} \mathrm{Ba}$ is foolish to sully the care for life.

Keep me from death until I come to it!

Sweeten the West for me!

Is it a disaster, after all?

Life is but a limited time-span;

even trees fall.

Tread on the lie, while my misery endures!

The Self pleads for waiting and patience. Life has an end and then there will be time for separation and reunion under different conditions. The Self is referring to the same judges of the dead whose impartiality the $\mathrm{Ba}$ had praised:

May Thoth judge me, he who appeases the gods!

May Khonsu defend me, he who writes truly!

May Re hear my speech, he who calms the sun barque!

May Isdes defend me in the sacred hall! ${ }^{14}$

${ }^{13}$ The same expression recurs in line 15: "He attacks me on the day of affliction." It refers probably to the day of death and the judgment of the dead.

${ }_{14}$ Berlin 3024, 23-27, Barta 13, 21. 
The Soul responds:

You are not a man. Are you not still living?

What is it that you want to bring to an end, caring about life as a possessor of treasures?

The word $\mathrm{km}$ "to finish, to bring to an end" resumes the theme of "time" which the Self had introduced with the sentence "life is but a limited time-span." The Self pleads for time, delay, waiting, patience; the Soul pleads for the "now," the actual moment. To this, the Self answers by pointing out what "treasures" or values it cares about, and what it understands by "life":

I said: I will not go as long as this is neglected.

Surely, you are running away without caring.

Every criminal says: "I shall seize you!"

Though you are dead, your name lives.

The "hereafter" is a place of rest, a place where the heart is leading to.

The west is a haven, if the voyage is difficult $[\ldots]$

If my Soul listens to me without malice, its heart in accord with me, it will be happy.

I shall make it reach the west like one who is in his tomb, after his survivor had appeared at his burial.

I shall make a cooling over your corpse, so that you will make envious another Soul in weariness.

I shall make a cooling but it shall not be freezing, so that you will make envious another soul which is hot.

I shall drink water at the pond over which I made shade, so that you will make envious another soul that hungers.

But if you are keeping me from a death like this, you will not find a place on which to rest in the west.

Be patient, my soul, my brother, until my heir comes, one who will make offerings, who will stand at the tomb on the day of burial, having prepared the bier of the graveyard.

Now it becomes clear that both the Self and the Soul long for death. Only the form and concept of death are controversial. The Self perceives death in the traditional way, as a continuation of the community of Self, Body, and Soul, but under different conditions. To the Self, death means the termination of this community. The death which the Self wants needs preparation and, therefore, time; thus the Self pleads for delay and waiting. To the Soul, this caring for afterlife and continuation seems illusory and superfluous. It answers the Self in the most brutal way by negating any hopes for a life after death: 
If you think of burial, it is heartbreak.

It is the bringing of tears by aggrieving a man.

It is taking a man from his house, casting (him) on high ground.

You will not go forth to see the sun.

We must realize that "to go forth" and "to see the sun" is the very center of Egyptian hopes and ideas about life after death. "Going Forth by Day" is the Egyptian title of the Book of the Dead. What the soul is denying constitutes the most sacred beliefs of the Egyptians; a more radically heretical voice is hardly imaginable. The Soul continues by striking up the tune of vanity that is a favorite topic of Egyptian banquet songs, ${ }^{15}$ but in such a brutal way as would never be permitted in entertainment poetry:

Those who built in granite, who erected halls in excellent tombs of excellent constructionwhen the builders have become gods, their offering stones are desolate, like those who died on the riverbank for lack of a survivor.

The flood takes its toll, the sun also.

The fishes at the water's edge talk to them.

Listen to me! It is good for people to listen.

Follow the feast day, forget worry!

It is the same song that the goddess Siduri sings to Gilgamesh in the Babylonian epic, in order to avert him from his futile quest for immortality: ${ }^{16}$ "Follow the happy days! Forget sorrow." Death is the

${ }^{15}$ Cf. "Song from the Tomb of King Intef," Lichtheim, AEL I, 194-197:

Those who built tombs, their places are gone.

What has become of them?

I have heard the words of Imhotep and Hardedef, whose sayings are recited whole-

what of their places?

Their walls have crumbled, their places are gone, as though they had never been.

None comes from there, to tell of their state, to tell of their needs, to calm our hearts,

until we go where they have gone.

Hence rejoice in your heart!

Forgetfulness profits you.

Follow your heart as long as you live!

${ }^{16}$ Cf. Tzvi Abush, "Gilgamesh's Request and Siduri's Denial," Part I: The Meaning of the Dialogue and its Implications for the History of the Epic," in M.E. Cohen et al., eds., The Tablet and the Scroll: Near Eastern Studies in Honor of W. W. Hallo (Maryland, 1993) 1.14; id., Part II: "An Analysis and Interpretation of an Old Babylonian Fragment about Mourning and Celebration," in Comparative Studies in Honor of Yochanan Muffs, JANES 22 (1993): 3-17. 
end, there is no return. The tombs fall into ruin, their possessors, as well as the poor who collapse on the road, are forgotten. The hereafter which the Self is dreaming of is pure illusion.

The Soul then goes on to illustrate this point by two parables dealing with a man and his wife. In both, the man shows an attitude typical of the Ba. The first parable is about a man who, after having plowed his plot, loads his harvest in a boat and embarks with his family for home. After sunset there is a storm. The boat founders, and his wife and children fall victim to the crocodiles. The man sits on the shore and breaks out crying:

I do not weep for her who was born, and that for her there is no return from the west for another being on earth.

I grieve for her children broken in the egg,

who have seen the face of death before they have even lived.

The meaning of the parable can be summarized as follows: "What is worse than death? Never to have lived at all." This sentence is the exact negation of that tragic wisdom of the Greeks and of Ecclesiastes: "It is better for men never to have been born. ${ }^{17}$

So I returned, and considered all the oppressions that are done under the sun: and behold the tears of such as were oppressed, and they had no comforter; and on the side of their oppressors there was power; but they had no comforter.

Wherefore I praised the dead which are already dead more than the living which are yet alive.

Yea, better then they both is he who hath not yet been, who hath not seen the evil work that is done under the sun. (Eccl. 4:1-3)

This motif also occurs in Egyptian texts, for example, the text known as Admonitions which belongs to the same genre as our Dialogue and shares the same topics and general attitudes:

Lo, great and small say: "I wish I were dead!"

Little children say: "He should not have made me live!"18

The Soul opposes this view by the paradoxical claim that to have never been born is the greatest misfortune.

The second parable deals with the topic of time and delay. A man asks for supper at the wrong time of day. His wife puts him off until the evening. He leaves the house in fury but comes back in the

17 Qoh 4.1-3.

${ }^{18}$ Admonitions, after Lichtheim, p. 153. 
evening "like another person." His wife knows him. He does not listen to anybody reproaching him and is "empty-hearted" - stubborn - to the message. The wife seems to play the role of the Self and the man that of the Soul. The Soul is the one who is impatient, does not want to wait, whereas the Self is preparing for the right moment. The theme of waiting versus impatient desire for "now" fits the overall course of the argumentation perfectly. However, if the "man" in the parable is really meant to play the part of the Soul, it is strange that the Soul portraits its own attitude in such a critical way. It is obviously the wife who is right in this story. Is there a confusion in the speakers? Is this parable to be put in the mouth of the Self, answering the parable of the Soul?

The next speaker in the dialogue of a man and his wife is, however, doubtlessly the Self: "I opened my mouth to my Soul to answer what it had said." What follows are four lyrical cantos. The first has eight short stanzas, all of them starting with the line "Lo, my name reeks because of you." Since the words "Lo" and "because of you" are homographs in Egyptian, a rendering such as "lo, my name reeks, lo ..." is equally possible:

Lo, my name reeks,

lo, more than carrion smell

On summer days of burning sky.

But I think that this interpretation is less probable. In this canto, the Soul is not speaking of a general situation of social disgrace; that is the topic of the second canto. The issue here is what becomes of the "name" after a death such as the Soul has in mind. Even before, the Self had reminded the Soul of the fact that the name survives after death and that for this reason man is responsible for his life and his preparation for death. If this preparation is neglected, the surviving name will be "reeking," it will be an abomination for posterity.

\section{Isolation, Solitude, and Personal Disintegration}

The second canto deals with the theme of solitude. The text is now obviously approaching the crucial experience that has caused the crisis of the person. It is the experience of total isolation, of an individual who cannot find anyone to speak to among his contemporaries, and who despairs at the impossibility of communication and community. 
To whom shall I speak today?

Brothers are mean,

The friends of today do not love.

To whom shall I speak today?

Hearts are greedy,

Everyone robs his comrade's goods.

To whom shall I speak today?

Kindness has perished,

Insolence assaults everyone.

(...)

To whom shall I speak today?

The criminal is one's intimate, the brother with whom one dealt, is a foe.

To whom shall I speak today?

Yesterday is not remembered,

No one acts for him who has acted, nowadays.

\section{(...)}

To whom shall I speak today?

Faces are blank,

Everyone turns his face from his brothers.

To whom shall I speak today?

Hearts are greedy,

No man's heart can be relied on.

To whom shall I speak today?

None are righteous,

The land is left to evildoers.

To whom shall I speak today?

One lacks an intimate,

One resorts to an unknown to complain.

To whom shall I speak today?

Wrong roams the earth, And there is no end of it.

The Egyptian idea of "Maat" or justice means precisely the spirit of mutual understanding, solidarity, and community that is the indispensable foundation of civil society. But here we have sixteen different images (we have omitted a few) that evoke the catastrophe of 
destroyed community, driving the speaker into an isolation he has not brought about by himself: lack of love, predominance of greed and avarice, disappearance of kindness, increase of violence, contempt of the just and the contention with evil, the transformation of friends into foes, the disappearance of memory, gratitude, and recompensation, the averted eyes and lack of unspoken understanding, loss of confidence, a lack of righteous people who allow others to live with them in good company, and general dissolution of society. This is a striking diagnosis of social disintegration, and the most impressive symptom, to my mind, is the one that occurs in the center of the long stanza:

To whom shall I speak today?

The past is not remembered,

No one acts for him who has acted, nowadays.

The decay of memory is here considered as one of the symptoms of social disintegration. To the Egyptian mind, memory is the social sense par excellence. If the past is forgotten, people no longer relate to each other, no longer repay good with good and evil with evil. In those times, the world will be "out of joint." This is a common complaint in literary texts of the Middle Kingdom. If the past is not remembered, social coherence disintegrates, and the world turns into an arena of general fighting, a bellum omnium contra omnes.

Lo people fight in the arena, for the past is forgotten. Success eludes him who no longer knows him whom he has known. ${ }^{19}$

In a text of the same time period we read: "a sluggard has no yesterday," ${ }^{20}$ that is, no past, no memory, no conscience, no responsibility. A person without memory is a "sluggard," a socially irresponsible individual such as the Self is complaining of. The opposite is the ideal, the responsible person who is able to remember:

A good character returns to his place of yesterday, for it is said: Do to the doer to make him do. It is thanking a man for what he does. ${ }^{21}$

${ }^{19}$ Instruction of Amenemhet I pMillingen 10f; Abschnitt V d-e in Wolfgang Helck, Die Lehre des Amenemhet (Wiesbaden, 1969) S. 35-37. Cf. Wolfhart Westendorf, in Göttinger Miszellen 46 (1981), S. 33-42, and Elke Blumenthal, in Zeitschr.fäg.Sprache 111 (1984), S. 88.

${ }^{20}$ Bauer B 2, 109f., Verf., a.a.O., S. 60.

${ }^{21}$ Bauer B 1, 109-110; Friedrich Vogelsang, Kommentar zu den Klagen des Bauern, Unters. z. Gesch. u. Altertumsk. Äg. 6 (Leipzig, 1913) S. 100. 
It is, of course, Nietzsche who, in our days, found the most impressive formulations to describe the social importance of memory. There is no society without memory, and vice-versa. Memory, according to Nietzsche, is a social institution, an "invention." He distinguishes a natural form of memory that cooperates with forgetting and regenerates through forgetting, from what he calls "the memory of the will" that he believes to be not only a human phenomenon but a human invention, a civilizational acquisition. This kind of memory is the exclusive property of man who is "the animal that is allowed to make promises."

Eben dieses notwendig vergessliche Tier, an dem das Vergessen eine Kraft, eine Form der starken Gesundheit darstellt, hat sich nun ein Gegenvermögen angezüchtet, ein Gedächtnis, mit Hilfe dessen für gewisse Fälle die Vergesslichkeit ausgehängt wirdfür die Fälle nämlich, dass versprochen werden soll: somit keineswegs bloss als ein passivisches Nicht-wieder-los-werden-können des einmal eingeritzten Eindrucks, ... sondern ein aktives Nicht-wieder-los-werden-wollen, ein fort-und-fort-wollen des einmal Gewollten, ein eigentliches Gedächtnis des Willens.

(Precisely this necessarily forgetful animal in which forgetting is a power, a form of strong health, has cultivated within himself a countercapability, a memory, that enables him in certain cases to suspend ("unhinge") forgetting, viz. in those cases where a promise is to be made: it is therefore not only a passive not-being-able-to-get-rid-of the engraved impression....but an active not-being-willing-to-let-loose, a permanent willing of what had once been willed, a veritable memory of the will. ${ }^{22}$

This, Nietzsche says, is the long history of the origin of responsibility and accountability, the process by which man became "calculable." This is the social function of memory. Memory conveys calculability, responsibility, accountability; in short, identity, the capability of being tomorrow the same as today and yesterday.

"Memory" and "love" are the two socially important faculties that enable man to live in company. I would propose to call them "connective virtues." We remember that the Egyptians conceived of a person as a plurality which during life is always threatened by disintegration but which, after the physical death, may be reintegrated by means of ritual, recitation, and also memory - that is, the connective virtues of others. A person can contribute during life to his or her reintegration and continuation after death in two ways: by leading such a life that will pass the judgment of the dead, and by developing

${ }^{22}$ Friedrich Nietzsche, Werke in drei Bänden, ed. K. Schlechta (München, 1960) Bd.II, S. $799 f$. 
and using connective virtues, such as memory and love, in order to be remembered by others. But woe to one who lives in a time when he is alone with his connective virtues and when there is nobody who responds to his love and memory! Social isolation threatens the personal system and leads eventually to personal disintegration.

\section{Death and the Other-World}

The third canto is that famous poem with the recurrent line "death is before me today":

Death is before me today

Like a sick man's recovery,

Like going outdoors after confinement.

Death is before me today

Like the fragrance of myrrh,

Like sitting under a sail on a day of breeze.

Death is before me today

Like the fragrance of lotus,

like sitting on the shore of drunkenness.

Death is before me today

Like a well-trodden way,

Like a man's coming home from warfare.

Death is before me today

Like the clearing of the sky,

As when a man learns what he ignored.

Death is before me today

Like a man's longing to see his home

When he has spent many years in captivity.

These verses do not seem to need any commentary. They sound only too familiar. But this, precisely, is our problem. They seem to express the Christian (and Jewish?) idea of dying as a return to God, the originally gnostic feeling of being a stranger in this world, of belonging to another world, and of returning home to that other world in death. This poem has entered the pious repertoire of Protestant and Catholic sermons.

Nothing, however, could be more opposite to Egyptian thought than this reading of the text. The Egyptian normally does not feel a 
stranger in this world; on the contrary, he feels strongly attached to it. All of Egyptian religion confirms this basic feeling of being at home in the world. The feelings that the Self expresses in its second and third songs rise from a fatal crisis, a catastrophic situation, an experience of estrangement from a world turned upside down, or "out of joint," as Hamlet says. It is absolutely scandalous for one to long for death, to see in it a liberation from confinement, a convalescence from sickness, a reunion after separation. These verses, instead of evoking a feeling of pious edification and consolation, should alarm and shock the reader. They are meant as paradoxes. "Death" (mwt) has an unequivocally negative and shocking ring in Egyptian. In normal language, this term is avoided; when people speak of dying, they use a word meaning "to land." Death (mwt) is what men hate; Life is what they love. This is the normal state of affairs in Egyptian semantics. "As sure as you love life and as you hate death" is the usual formula in the tombs, invoking the visitor to say a prayer for the deceased. The Egyptian does not belong to the other world, but to this world, and if the bonds of belonging are broken and the individual falls into isolation, there is nothing to receive him into another worldly network of belonging.

Yet this seems to be the rather exceptional, even revolutionary, message of our text. The last and shortest canto of the Self continues:

Truly, he who is yonder will be a living god, punishing the evildoer's crime.

Truly, he who is yonder will stand in the sun-barque, Making its bounty flow to the temples.

Truly, he who is yonder will be a wise man,

Not barred from appealing to Re when he speaks. ${ }^{23}$

These verses describe the forms of belonging that await the person in the other world. He is performing three exemplary actions of connectivity: punishing the crime, providing the temples, speaking (and being listened to) as a wise man (because in a world where nobody listens, wisdom is of no avail). This is the kind of behavior that flows from connective virtues and that helps to build and maintain a community. The Self knows itself to possess these virtues, but despairs of this

${ }^{23}$ Berlin 3024, 142-147; Barta, a.a.O., 18, 28, 47; Goedicke, a.a.O., 178-182. Cf. with the last couplet a Coffin Text from Kom el Hisn, quoted after A. Loprieno, in Topos und Mimesis 97: "May you sit beside Re, may he listen to your speech." 
world as a place to bring them to fruition. The community that he longs for is no longer possible "here" and only to be hoped for "there."

This, however, is not the normal state of affairs. Like the biblical book of Job, the text constructs an extreme situation, a Grenzsituation (frontier situation) as Karl Jaspers puts it, and offers a last resort in extreme states of hopelessness and desperation. It is a text that processes extreme experiences of isolation and provides a kind of relief in being read aloud to a person. In much the same way as the book of Job, it speaks the language of despair and thus gives voice to those who feel themselves reduced to speechlessness in similar situations.

The principal difference between the Egyptian text and the book of Job is the concept of a hereafter, a question that Spinoza brought up in the seventeenth century and caused considerable scandal in the Jewish and Christian world. Spinoza discovered that the Hebrew Bible does not know of the immortality of the soul, of a hereafter and a future state of reward and punishment. Reward and punishment have to happen in this world alone, and if an individual does not live to receive it, it will be received by his posterity up to the third and fourth generation. This is the Mosaic conception, and for Spinoza it was proof enough that such a belief could not come from God. The Christian bishop William Warburton wrote a nine-volume work to prove Spinoza's observation true, but also to refute his conclusion. ${ }^{24}$ Ancient Egypt played an important role in this discourse as the exemplary religion of immortality and of a future life depending on reward and punishment.

It is true that Egypt had an idea of post-mortem recompensation that is lacking in Israel; Job will receive the reward for his virtue in his old age, whereas the Self in the Egyptian text expects the fulfillment of the longing to belong in the future life. But there is another important difference between Egypt and Israel, which points in the opposite direction. The biblical construct of belonging or connectivity is twofold; the Egyptian one is simple. The Jew belongs to God and to his people. He is responsible to both, and he constantly lives in the presence of both. Job, in conversing with his friends, is simultaneously addressing God. The Egyptian is alone with his Soul. He does not accuse the gods for his misfortune, nor does he perceive his sufferings as unjust punishments for crimes he did not commit. He knows that

${ }^{24}$ William Warburton, The Divine Legation of Moses, in nine Books (London, 1737-42). 
the gods do not interfere in human affairs, and that a human being is exposed to all kinds of misfortunes that have nothing to do with the gods and have no religious significance whatsoever. They just occur. The only way to address the gods and to enter into forms of belonging and connectivity that bind him to the gods is to die and to present himself to the judgment of the dead. The Egyptian does not conceive of himself as living simultaneously in two different worlds or systems of connectivity, one connecting him with his people, the other with god or the gods. He cannot find any consolation in the thought that when he is not loved and remembered by his fellows there is always a god who loves and remembers him. He lives in only one coherent sphere of connectivity that extends over his earthly and his future life; and the borderline between the two is marked by the judgment of the dead.

\section{Personal and Social Coherence}

The Egyptian individual is dependent on social coherence in order to be able to maintain his personal coherence. The Egyptian ideal is constellative integratedness, which depends on both the person's connective virtues and the social conditions. It is strange that our text says so little about the causes that have brought about this total disintegration of society. However, other texts are so explicit about this, that the text may have assumed this to be common knowledge, unnecessary to be made explicit. It also seems that there are some very basic semantic presuppositions that are so characteristic of a specific genre that they too are implicitly understood. Our text belongs to the genre of lamentations, most of which are cast in the form of an interior dialogue or monologue. Usually, these texts are more explicit as to the causes that brought about the lamentable state of affairs. The Lamentations of Khakheperresenb, from which we cited a passage, state that "Maat is cast out, Isfet reigns in the council hall." ${ }^{25}$ This text attributes the catastrophic situation of the land (that is, society) to the expulsion of Maat and the rule of Isfet. Maat is the principle that creates society, makes people live together in harmony, and brings about mutual love and memory. It is the principle of social and cosmic connectivity. The Egyptian term is usually translated as truth, justice, order; however, I have proposed to render the term as connective justice. It is the principle that creates (a) social space by

${ }^{25}$ Khakheperresenb, after Lichtheim I, p. 147. 
binding people together, (b) social time by tying yesterday to today and tomorrow, and (c) meaning by tying rewards to good actions and punishments to crimes.

But Maat is not a divine substance that simply is there and works its effects in some mysterious way, nor is it an inbuilt mechanism, such as the laws of nature, that functions automatically. It is something that people must practice by doing it and saying it. Without the active cooperation of men and women, Maat cannot subsist in the world and Isfet will take over.

Maat is both a social and a political category. Men and woman can only practice Maat if there is a state. The Egyptian terminology is that the king is responsible for the creation of Maat (shpr, to bring into being, to realize), and the people are responsible for practicing Maat in words and deeds (to say Maat, to do Maat). Another text of the same genre makes it clear that it is the collapse of the state and the lack of kingship that is the ultimate cause of the catastrophe:

See now, things are done that never went before,

the king has been robbed by beggars.

See one buried as a hawk is [cast on the desert]

What the pyramid hid is empty.

See now, the land is deprived of kingship

By a few people who ignore custom.

See now, men rebel against the Serpent,

[stolen] is the Crown of Re, who pacifies the two lands.

See, the secret of the lands, its limits are unknown,

if the residence is stripped, it will collapse in a moment.

(...)

The secrets of Egypt's kings are bared,

See, the residence is fearful from want. ${ }^{26}$

Another example comes from a lamentation that is overtly political, the prophecy of Neferty. Here, a sage prophesies future calamities, addressing his heart in the usual form:

Stir, my heart, bewail this land, from which you have sprung!

When there is silence before evil,

And when what should be chided is feared,

Then the great man is overthrown in the land of your birth.

Tire not while this is before you,

Rise against what is before you!

Lo, the great no longer rule the land,

${ }^{26}$ Admonitions, after Lichtheim I, pp. 155f. 
what was made has been unmade,

Re should begin the creation again. ${ }^{27}$

From the very start it is clear that the description refers to a state of interregnum. But at the end, a savior-king is announced:

Then a king will come from the South,

Ameny the justified is his name,

$\ldots$

Rejoice, O son of a woman of Ta-Seti, child of Upper Egypt.

He will take the white crown,

he will wear the red crown

people of his time,

The son of man will make his name for all eternity!

The evil-minded, the treason-plotters,

they suppress their speech in fear of him;

Then Maat will return to her seat

while Isfet is driven away. ${ }^{28}$

These texts are explicit about the causes of the general situation, that the dialogue keeps in the dark or silently presupposes. Generally speaking, the genre of lamentations is a socio-political discourse reflecting on the conditions of civic society and social harmony. In the context of this genre, our text holds a rather exceptional position in that it excludes every social, political, and historical condition and focuses solely on the interior bonds of love and memory. A predominantly social and political discourse is turned into an anthropological one. Its theme is not society or the state, but the person. The problem to be solved is not the legitimation of kingship and social order, but the question of death, and how Self and Soul can survive and the Person persist in such a crisis.

The basic problem is what an individual does with his or her own solitariness in the context of a culture that constructs the person in terms of plurality. How can a person built on communication and constellation persist when communication fails and constellations break? It is the same question that underlies Whitehead's famous definition: "Religion is what an individual does with his own solitariness. ${ }^{~} 29$ The answer that the Dialogue of Self and Soul provides is the answer of religion. It is not the only one. Five hundred years from now, the answer will be radically different; but that is another story.

${ }^{27}$ Neferty, Lichtheim, pp. 140f.

${ }^{28}$ Neferty, Lichtheim, p. 143.

29 A.N. Whitehead, The Making of Religion (Cambridge, 1927) p. 6. 